\title{
Errors-based Rehabilitation within Phonological Framework: Segmental Changes in Broca's Aphasia
}

\author{
I Ketut Wardana \\ Mahasaraswati Denpasar University, Denpasar, Bali, Indonesia \\ I Nyoman Suparwa \\ Udayana University, Denpasar, Bali, Indonesia \\ Made Budiarsa \\ Udayana University, Denpasar, Bali, Indonesia \\ Anak Agung Putu Putra \\ Udayana University, Denpasar, Bali, Indonesia
}

\begin{abstract}
The studies of phonological therapy for patients with both phonemic planning and articulatory implementation deficits report the related dichotomy of anterior and posterior syndrome with psycholinguistic model. However, there must be some investigation on segmental errors as input of rehabilitation within phonological framework. This study investigates whether the errors-based rehabilitation model can encourage two Balinese individuals with Broca's aphasia (KW and NS) to reduce the phonological errors. The results showed that KW and NS performed different segmental errors and types of the phonological process even though they suffered from identical non-fluent symptom. $\mathrm{KW}$, in pre-intervention tended to present phonemes substitution, omission and insertion errors which mostly occurred in the initial position of words and he transposed the onset of the second syllable to the onset of the first syllable. Meanwhile, NS in some cases, tended to transpose the phonemes randomly, inserted other segments - especially [nasal] and [lateral] between two vowels (hiatuses) and altered the high complex segments with less complex ones. The phonological errorbased rehabilitation was effective to reduce the errors and the phonetic relaxation helped them exhibit minor errors. This indicated that phonetic based training can stimulate the articulatory processing deficit as anterior syndrome.
\end{abstract}

Index Terms—phonological errors, rehabilitation, non-fluent, generative phonology

\section{INTRODUCTION}

Phonological rehabilitation for speech output of patients with aphasia has been broadly conducted as linguistic and clinical efforts to fix the phenomenon of both phonemic planning and phonetic processing errors. Many previous rehabilitation studies on speech output of aphasics with phonemic planning deficit are concerned with phonological analysis as theoretical bases on the phoneme substitution, omission and insertion errors. Robson et al (1998) applied phonological awareness therapy by stimulating the patients' ability in articulating the first phonemes of syllable structure, while Howard (1995) has applied semantic therapy including word-picture matching, finding meaning of words, and explaining the word clues. For more specific analysis on impaired system of language function due to brain pathology, many studies have referred to the psycholinguistic model. Muso et.al (1999) committed training the brain flexibility of aphasics and measurement through the token test correlated to cerebral blood flow in their brain. In other cases, Kendall et.al (2003), Pascoe, Stackhouse \& Wells (2004) have applied the combination of those approaches. Furthermore, to describe the correlation of phonological errors with the natural language function of the brain, Kemmerer (2014) and Bambini (2012) have applied descriptive cognitive neuroscience in the prospective of neurolinguistic approach. However, the phonological approach is worth applying to analyze and rehabilitate the phonological errors.

The application of the patients' phonological errors-based rehabilitation has not been conducted yet, therefore, those errors are worth analyzing with phonological theory as an input of the intervention strategy. In addition, it is primarily required to explore the process of errors-fixing efforts with a descriptive method without concerning the efficacy of the outcomes that requires experimental approaches to generalize the results. The descriptive analysis focuses on both phonemic planning deficit and articulatory implementation deficits because the failure of articulating the sounds by Broca's aphasic patients is associated with the impaired phonetic processing level in anterior site. Gandour (1992) poses that "articulatory implementation deficits are circumscribed to anterior lesions" (p. 207). Meanwhile, Bastiaanse, 
Gilbers \& Linde (1994) underline that some Broca's aphasics also produce a considerable number of phonemic errors, due to a disorder in phonetic processing, namely, planning and executing the articulatory programmes.

Concerning the traditional dichotomy between anterior and posterior syndromes, Gandour (1998) describes that anterior aphasics exhibit deficiencies in articulatory implementation, whereas the consonant production deficits of posterior aphasics reflect problems of phonological nature (p. 210). For example, the Balinese word guru 'teacher', which is realized as [kulu] by a patient with Broca's aphasia is considered as the failure of phonemic processing because one segment is substituted or inserted by another segment. These errors are assumed to be attributed to a breakdown in phonological processing in the posterior zone, that is, in transforming the underspecified lexical phonological form into a phonemic representation (Bastiaanse, Gilbers \& Linde, 1994). However, some Broca's aphasic patients mainly exhibit inaccurate articulation, prolongation and devoicing. Cera \& Ortiz (2010) argue that distortion and devoicing are considered as a substitution type of errors since one phoneme is replaced by another (p. 59). For this case, the analysis of generative phonology is considered appropriate to describe the phenomenon. Meanwhile, the errors at a phonetic level in the word guru above occurs due to the articulatory implementation deficits in temporal parameters of consonants and vowels in segmental co-articulations of /g/ with /u/ and of /r/ with /u/. Romani \& Calabrese (1998) put it that in a cognitive framework, "phonological errors can be attributed to different stages of a production model: they may arise because the correct entry in the phonological lexicon cannot be accessed because of an articulatory planning deficit. If a sequence of phonemes is too complex to be produced, it may be simplified by deleting, inserting, substituting, or transposing phonemes" (p. 83).

Considering that statement, phonological awareness therapy consists of principles, namely developing stimuli programs, selecting certain procedure and purpose, and setting the material and therapy schedule. This procedure requires some knowledge of what can be done by therapists and what can be performed by patients. There are three principles of direct rehabilitation; (i) natural therapy is the oldest approach that claims the dysfunction of the brain and the cause of aphasia can be restored so that it can function again; (ii) process approach therapy is conducted to modify the process that causes the aphasia, including the increasing auditory and visual perception, activating cortex function in reorganization, and reintegration of memory for language and the right hemisphere involvement; and (iii) communication approach therapy is conducted to develop patients' communication modality even though she or he is suffering from aphasia. Associated with natural therapy, Blumstein (1973), Novick et.al (2010), Sengkey \& Pandeiroth. (2014) and Kemmerer (2014) report that the damage to the left perisylvian language structures typically results in one of the classic aphasia syndromes. Therefore, this study analyzes the segmental errors in two parameters, namely consonants and vowels in a sequence of syllables produced by the patients and rehabilitate them by stimulating the articulatory planning to achieve the closer-normal conditions. The rehabilitation model is applied not only to change the condition of phonological errors but also to maintain communication awareness.

\section{LITERATURE REVIEW}

As consideration, previous studies of aphasia therapy may provide a lot of empirical information, and one of the most common is known as phonological awareness therapy. This type of phonological analysis-based therapy is a conception of word-sound structure or from syllable to phoneme (Benson, 1979). Meanwhile, phoneme awareness is the subtype of phonological awareness that refers to certain knowledge of every phoneme in a word (Hesketh, 2009). Stimulation training is considered prominent and significant for aphasic patients in order to increase reorganization of neuroplasticity in the cortical area (Robson et.al, 1998, Muso et al.1999, Hesketh et.al, 2000, Kendall et al. 2003, Pascoe, Stackhouse \& Wells, 2004). So, this study submits that phonological awareness therapy can strengthen the stimulation.

Furthermore, Robson et.al (1998) claim that naming therapy effectively influences the preexisting condition of anomia by generalizing other items. With the cognitive neuroscience approach, Muso et.al (1999) expose 'Traininginduced brain plasticity in aphasia' in Brain describes the impaired naming aspects of four patients with aphasia due to the lesion in superior temporal gyri. Kendall et.al (2003) claim that the phonologically-based treatment programme utilized in the study was effective in the treatment of the indirect process with some effect of generalization to behaviors such as consonant repetition, non-word repetition, real word repetition and auditory syllable discrimination. Meanwhile, Radman et.al (2016) claim that left parietal temporal modified the brain networks engaged in the phonological-phonetic processing during naming only in the trained language for the trained items.

However, the present study tries to provide evidence of phonological errors and rehabilitate the errors based on a phonological approach. Related to the analysis of segmental errors, Gandour (1998) argues that "the recent theory of generative phonology which analyzes features of phoneme substitution errors of aphasic patients is categorized as phonemic errors recognized in hierarchical tree structure" (p. 209). Meanwhile, Schane (1992) claims that "the phonological process can be explained as an articulatory phenomenon" (p. 61) and Gandour (1998) believes that articulatory planning is operated in the anterior of the left brain, so there must be a natural way to stimulate the impaired part. Gandour (1998) poses that anterior aphasics tend to produce phonetics errors due to the failure of a phonetic processing stage ascribed to a breakdown in planning the phonological messages. The types of errors in the anterior stage are distortion, prolongation, and devoicing. The failure to present correct sequences of sound precision is characteristic for the speech of Broca's aphasia (Lesser, 1995), meaning, the Broca's aphasic patients do not have 
problems with selecting the right words, but in realizing them. Based on this notion, the phonological errors of Broca's aphasia will be worth discussing and treating them with generative phonology and phonetic side of views. Several new developments in phonetics and phonology emphasize that phonetic substance interacts with phonological structure (Ziegler \& Aichert, 2015).

The primary aim of the present study is to identify the types of segmental errors and investigate the phonetic realization of speech output of patients with Broca's aphasia after a phonological errors-based rehabilitation model is applied. The following research questions were posed: (1) What incorrect sounds are articulated in pre-intervention? (2) How does the sequence of phonological errors-based rehabilitation model work? (3) What correct sound outputs are produced after the intervention is conducted?

\section{METHOD}

\section{A. Participants}

The first participant, $\mathrm{KW}$, is a 70-year-old, a right-handed male with a BA degree in teaching and was employed as an elementary school teacher prior to the onset of a left middle cerebral artery cerebral vascular attack in 2017. The second participant, NS is a 52-year-old, a right-handed male, and a wood carver. He had Broca's aphasia too and right hemiplegia immediately following the non-hemorrhagic stroke (NHS) in 2018. Both participants had the same syndrome of non-fluent aphasia, such as difficulties in repeating words, phonological anomia, naming, reading, and writing. Mostly, they have problems initiating an utterance, with groping movements, multiple false attempts (as in Balinese word ngelah 'have' is realized as [gege.. ge.. ge.. ige ige ulih yalek yulih] and self-correction (as in word aluh 'easy' is realized as [lul..al.luh]).

\section{B. Instruments}

The participants' speech output was stimulated by different eliciting phonological tasks, e.g, and word-picture matching stimulation. They were given phonological tasks consisting of 260 simple and complex target words. These words or pictures mainly represented consonants and vowels in different distributions, including consonant clusters. The speech was digitally recorded using a SONY MP3 player. The observation of the recorded speech was conducted by classifying types of phonological errors including phonemes substitution, distortion, insertion, omission, and metathesis. The segmental errors were counted and transcribed phonemically and phonetically in accordance with I.P.A by one of the authors (INS). The data were copied and measured in speech analyzer to ensure the acoustic features of single sound. The acoustic measurement may provide any phenomenon of articulation errors.

\section{Procedures}

Word naming, picture naming, spontaneous speech, and oral reading, which were performed by the participants, can provide information about any syndrome of non-fluent aphasia, determination of sound severity and the change of segmental errors. The speech output of the participants was obtained by observing and noting the segmental errors of vowels and consonants. Every consonant error was classified based on the place and manner of articulation group, e.g., bilabial, alveolar, velar stop, alveolar fricative, alveo-palatal affricative, liquids or glides so that the description of phonological errors can provide an accurate analysis. These inputs were then treated in a mechanism of errors-based rehabilitation model which is grounded by the phonological approach. A program of speech training was applied to know exactly the physical property of impaired sound and types of errors occurred. Therefore, the mechanism of phonological rehabilitation was applied to fix them and to achieve a certain range of close to normal condition. The concepts of the errors-based rehabilitation model are manifested in three strategies, such as phonetical relaxation, suprasegmental repetition, and segmental simulation, each of which is supported by procedures and better segmental change possibility. The mechanism of the error based rehabilitation model is presented below. 
TABLE I.

MECHANISM OF ERRORS -BASED REHABILITATION MODEL

\begin{tabular}{|c|c|c|c|}
\hline & Phonetic relaxation & Suprasegmental drill & Segmental simulation \\
\hline Step 1 & $\begin{array}{l}\text { Inform the patients that the } \\
\text { rehabilitation is conducted to reduce } \\
\text { the segmental errors, not to cure the } \\
\text { medical condition. The program was } \\
\text { started with a supportive approach to } \\
\text { increase their motivation and } \\
\text { awareness of communication. }\end{array}$ & $\begin{array}{l}\text { Words and pictures that were failed to } \\
\text { be articulated correctly by the patients } \\
\text { were treated in this strategy, e.g, /siap/, } \\
\text { /selem/, /panak/. The word was then } \\
\text { uttered } 3 \text { times without any rhythm and } \\
\text { melody and then recorded. Another } \\
\text { recording was conducted to repeat those } \\
\text { words without melody. }\end{array}$ & $\begin{array}{l}\text { The mechanism and objective of } \\
\text { the phonological rehabilitation } \\
\text { were informed to the patients } \\
\text { before the training was conducted. }\end{array}$ \\
\hline Step 2 & $\begin{array}{l}\text { The identified segmental errors are } \\
\text { classified based on the features, } \\
\text { e.g, .main class features [+obstruent] } \\
\text { namely }[p, t, k, b, d, g, c, j, s, h] \text { and } \\
{[+ \text { sonoran] such as: }[a, i, u, e, o, \partial, m \text {, }} \\
\text { n, y, y, w. r, l]. }\end{array}$ & $\begin{array}{l}\text { The headset was put in patients' left } \\
\text { ears and the recorded words without } \\
\text { melody were played. }\end{array}$ & $\begin{array}{l}\text { The segmental errors were repeated } \\
\text { in sequence with vowels } \\
\text { individually by the researcher and } \\
\text { the patient was asked to look at the } \\
\text { action of the articulators, e.g., [p], } \\
\text { [b] or reverse order [b], [p] and [pa] } \\
\text { [ba] or [ba] [pa] simultaneously. }\end{array}$ \\
\hline Step 3 & $\begin{array}{l}\text { The patients were requested to } \\
\text { combine the consonant errors with } \\
\text { vowels, e.g,; /na/, /na/, /si,//si/, /se/, } \\
\text { /se/ , /la/, /la/ /le/ /le/ in rytm of a } \\
\text { song. }\end{array}$ & $\begin{array}{l}\text { The patients repeated those words three } \\
\text { times, /siap/, /selem/, /panak/.. /siap/, } \\
\text { /selem/, /panak/...and switch them in } \\
\text { correct phrase //panak/, /siap /, / selem } \\
\text { //. }\end{array}$ & $\begin{array}{l}\text { Pictures that were started by stop } \\
\text { sounds were shown and the patients } \\
\text { were asked to say and change the } \\
\text { pictures that were started with } \\
\text { fricative and affricative sounds. }\end{array}$ \\
\hline Step 4 & $\begin{array}{l}\text { The patients were shown pictures } \\
\text { concerned with treated sounds, e.g,. a } \\
\text { picture of rice and sweet potato 'nasi' } \\
\text { and 'sela' respectively. /nasi/, /sela/. }\end{array}$ & $\begin{array}{l}\text { The head set was open and patients } \\
\text { were asked to repeat the words three } \\
\text { times. [eyap], [kuleb], } \\
\text { [pilanak],[eyap], [kuleb], } \\
\text { [pilanak],[pilanak],[eyap], [kuleb]. }\end{array}$ & $\begin{array}{l}\text { One sentence was uttered, a picture } \\
\text { was shown to patients, and they } \\
\text { completed the last syllable e.g, : } \\
\text { Ipanake tuni meli to...(pictures of } \\
\text { tomato). }\end{array}$ \\
\hline Step 5 & $\begin{array}{l}\text { The picture of the words, e.g, 'nasi } \\
\text { sela'were shown and the patients } \\
\text { trained to utter more complex words } \\
\text { without context. }\end{array}$ & $\begin{array}{l}\text { The headset was put in patients' right } \\
\text { ears and the recorded words with } \\
\text { melody or rhythm were played } 3 \text { times. }\end{array}$ & $\begin{array}{l}\text { Words were repeated by cutting off } \\
\text { the last syllable related to the } \\
\text { pictures and completed by the } \\
\text { patients. }\end{array}$ \\
\hline Step 6 & $\begin{array}{l}\text { The patients were encouraged to } \\
\text { complete the eliciting words } \\
\text { concerning the pictures given e.g, } \\
\text { //tian meli.........//' I buy .... \{picture } \\
\text { of rice) or ask them /dija meli } \\
\ldots \text { where do you buy }\{\text { picture of rice }\} \text {. }\end{array}$ & $\begin{array}{l}\text { The head set was opened and the } \\
\text { patients were asked to repeat the word } \\
\text { they heard. //panak//siap/ selem//. The } \\
\text { patients were given pictures referring to } \\
\text { the words heard in the headset and } \\
\text { asked to say them. }\end{array}$ & $\begin{array}{l}\text { Sequences of pictures that have } \\
\text { more complex syllable patterns } \\
\text { were given to the patients, and the } \\
\text { first syllable were left } \\
\text { unmentioned, and the patients } \\
\text { completed them. }\end{array}$ \\
\hline Step 7 & $\begin{array}{l}\text { Evaluation was applied to measure the } \\
\text { level of phonological correctness } \\
\text { which was compared with the errors } \\
\text { in pre-intervention.. }\end{array}$ & $\begin{array}{l}\text { The patients were encouraged to train } \\
\text { the consonant errors in such a way, like } \\
\text { the word 'ngelah' which was said } \\
\text { [gege.. ge.. ge.. ige ige ulih yalek } \\
\text { yulih]. }\end{array}$ & $\begin{array}{l}\text { Patients mentioned the complex } \\
\text { words without the pictures or any } \\
\text { other clue. A combination of } \\
\text { segmental clusters was given to } \\
\text { encourage the patients to practice } \\
\text { the articulators. }\end{array}$ \\
\hline
\end{tabular}

The level of severity and possible change of phonological errors were measured by counting the total number of errors either in pre-intervention or post-intervention. The test, which was conducted in pre-intervention and postintervention, was used to measure the pre-existing speech outputs of the participant and the post-test was given after the intervention of the error-based rehabilitation model was applied.

\section{Data Analysis}

A phonological analysis on segmental errors, including substitution, distortion, omission and insertion was carried out and treated as inputs of intervention. All errors that occurred across all tasks were analyzed. This analysis was performed based on the distinctive features model proposed by Schane (1992) and used the segments matrix for the Balinese language. The features contained in this matrix include: syllabic, consonantal, sonorant, anterior, coronal, continuant, strident, delayed release, nasal, lateral, high, low, back, rounded and voiced. The phonological process such as assimilation, syllable structure, and simplification were observed in order to understand the reason of errors, e.g., the influence of neighboring phonemes. All the inputs were then classified based on the grade of complexity in articulation: stops $\rightarrow$ affricative $\rightarrow$ fricative $\rightarrow$ nasal $\rightarrow$ liquids $\rightarrow$ glides $\rightarrow$ vowels. The segmental errors were rehabilitated through the error-based rehabilitation model. All changes or outputs were analyzed to understand the phonological process by applying the theory of phonology. The number of errors in pre-intervention was compared with the phonemes rehabilitation to find out the different value as the outputs of the present study. Any phenomenon found in the rehabilitation was described as either phonetically or phonemically based features.

\section{RESULTS AND DISCUSSION}




\section{A. Pre-intervention}

The speech output of KW and NS was considered severe in terms of word naming, pictures naming, spontaneous speech, and oral reading. In 65 words in naming tasks, KW made 21 correct realizations or $0.32 \%$, in picture naming he made 25 or $0.40 \%$ correct phonemes, in answering questions, there were 19 or $0.29 \%$ correct phonemes, in oral reading, he scored 22 or $0.34 \%$ correct sounds. Based on the criteria of 5 of aphasia severity rating scale of the Boston test, KW had $1.35 \%$ correct sounds and 3.48\% incorrect sounds. Meanwhile, 65 words in each task, NS in word naming made 19 or 0.29 correct sounds, 27 or $0.41 \%$ correct sounds in picture naming, 15 or 0.23 correct phonemes in answering the questions, and 13 or $0.20 \%$ correct phonemes in oral reading. NS had $1.13 \%$ correct and $3.87 \%$ incorrect target words. Of the four types of errors, phonemes substitution errors were highly dominant and the least was phonemes omission errors. The number of omissions occurred more in onset of syllables than in coda. These errors were then counted and analyzed for further treatment.

Based on the distribution of phonological errors in 4 different phonological tasks, KW made $65 \%$ phonemes substitution errors, $20 \%$ phonemes distortions, 5\% omission errors and $10 \%$ insertion errors. NS made $68 \%$ phoneme substitution errors, $20 \%$ distortion errors, $11 \%$ omission errors and $1 \%$ insertion errors. Considering the phonemes substitution errors above, it was found that the stop sounds could not be articulated completely well due to the complexity of closure articulation. The segments of $/ \mathrm{p} /, / \mathrm{t} /, / \mathrm{k} /, / \mathrm{d} /, / \mathrm{t} /, / \mathrm{g} /, / \mathrm{P} /$ were mainly substituted by unvoiced alveolar fricative [s], as well as the trill sound /r/ was realized as lateral [1] in all positions because the patients could not rise, vibrate and glide the tongue across the hard palate. This study supports the statement of Romani \& Calabrese (1998) that this type of simplification occurs in Broca's aphasia due to "the failure in phonetic processing" (p. 83-84). So in short, the patients simplified those stop sounds by substituting them with more sonorant segments in sonority scale (Bastiaanse, Gilbers \& Linde, 1994). From the articulatory deficits side of view, "the realization error of unvoiced fricative sound was associated in such a way with place of articulation and difficulties in vibrating the vocal cords during the process of phonation" (Lieberman \& Blumstein 1988, p. 101). The articulation of [s] was easier to be articulated due to the simple mechanism of releasing the airstream from the oral tract. Concerning the devoicing, as Cera \& Ortiz (2010) found that "the voiced segment was mostly affected by the unvoiced segments" (p. 60). A unique phonological rule of the substitution errors uttered by KW was in the word of kasur 'matrass', which was realized as [satul].

This study also found that the voiced segments $/ \mathrm{b} /, / \mathrm{d} /, / \mathrm{g} /$ were realized as unvoiced stop sounds [p], [t] and [k], however the unvoiced segments such as $/ \mathrm{t} /$, $/ \mathrm{k} /$ were realized as voiced sound $[\mathrm{n}]$ and [b]. Some articulatory- based segments, in this case, had forwarding processes, e.g., velar sounds $[\mathrm{k}],[\mathrm{g}],[\mathrm{y}]$ were substituted by alveolar sounds [t], [d], [n], [s] and [1]. The alveolar sounds were altered by bilabial sounds [p], [b], [m]. The complex articulation of /s/ or / $\mathrm{k} /$ was simplified by substituting them with a glottal fricative sound [h]. In small percentage, the unvoiced segments were substituted by voiced segments. Referring to vowel substitution errors, the complexity of high vowels /i/, /u/ were substituted by low vowel /a/ or lower unrounded vowel /o/ as well as tense vowels /i/, /u/, /e/ were substituted by lax vowels /I/, /U/ and /ə/. Concerning the phonemes insertion errors, vowels that were mostly inserted were /i/, /o/, /u/, /a/ meanwhile, the inserted consonants were mainly $/ \mathrm{h} /, / \mathrm{k} /$, and $/ \mathrm{l} /$ in the onset of a syllable. This occurred mainly in onset. e.g: the word manas 'pineapple' was realized as [manles]. The segment /1/ was at the onset of the second syllable. Omission of $/ \mathrm{k} /, / \mathrm{t} /$, and $/ \mathrm{p} /, / \mathrm{y} /, / \mathrm{w} /$ that occurred in initial, medial, and final distribution indicated the most complex articulation to be produced by KW and NS.

\section{B. Phonetic Relaxation}

Based on the segmental errors above, it can be reported that the phonemic and phonetic errors in speech outputs produced by the patients with Broca's aphasia is considered significant for further rehabilitation processes. The first strategy of the error-based rehabilitation model, which is called phonetic relaxation, was applied to stimulate the phoneme and phonetic awareness to change the initial condition of articulatory deficits. The training was focused on the way or how to combine one segment to another. The segments treated were $[\mathrm{p}],[\mathrm{t}],[\mathrm{k}],[\mathrm{b}],[\mathrm{d}],[\mathrm{g}],[\mathrm{s}],[\mathrm{c}],[\mathrm{y}],[\mathrm{r}],[\mathrm{w}]$ in initial position and the trained vowels were $/ \mathrm{i} /, / \mathrm{u} /, / \mathrm{o} /$. The difference of sound outputs between pre-intervention and post intervention of two participants can be presented below.

1. Speech Outputs of KW

After the sounds articulatory training in phonetic relaxation, the abnormal segments in speech outputs of KW became closer to the normal variation in terms of either place or manner of articulation in sequencing sounds. Some segments were not able to be sequenced with other segments though the participants were able to articulate them individually. The difficulty of blending the sounds together made KW choose the less complex segments, e.g., from voiced features to unvoiced, from high features to low, or from coronal feature to anterior. To find out the significance of the rehabilitation, the segmental errors in pre-intervention and post intervention can be presented below. 
TABLE II

THE Distribution OF ERRORS PRODUCED by KW IN PHONETIC RELAXATION

\begin{tabular}{|c|c|c|c|c|c|c|c|}
\hline No & Word naming & $\begin{array}{l}\text { Target } \\
\text { word }\end{array}$ & target segment & $\begin{array}{l}\text { Segment } \\
\text { realization }\end{array}$ & $\begin{array}{l}\text { Segmental } \\
\text { errors }\end{array}$ & $\begin{array}{l}\text { Post } \\
\text { Intervention }\end{array}$ & $\begin{array}{l}\text { Segmental } \\
\text { error }\end{array}$ \\
\hline 1 & Roko 'cigarette' & /roko/ & $/ \mathrm{r} /, / \mathrm{k} /$ & [lokoh] & {$[1],[\mathrm{h}]$} & [loko] & {$[1]$} \\
\hline 2 & Katos ‘tuff’ & /katos/ & $/ \mathrm{k} /, \mathrm{tt} /, / \mathrm{o} /, / \mathrm{s} /$ & [hastuh] & {$[\mathrm{h}],[\mathrm{u}],[\mathrm{h}]$} & [katoh] & [h] \\
\hline 3 & Kapak 'axe' & /kapak/ & $/ \mathrm{k} /$ & [hapah] & {$[\mathrm{h}]$} & [papak] & {$[\mathrm{k}]$, } \\
\hline 4 & Matah 'raw' & /matah/ & $/ \mathrm{t} /$ & [madah] & [d] & [mat..tah] & - \\
\hline 5 & Papat 'four' & /papat/ & $/ \mathrm{t} /$ & [papas] & [s] & [papat] & - \\
\hline 6 & & /sate/ & $/ \mathrm{t} /$ & [sake] & {$[\mathrm{k}]$} & [sat...te] & - \\
\hline 7 & 3 & /siap/ & /i/ & [seap] & [e] & [siap] & - \\
\hline 8 & & /tabuan/ & $/ \mathrm{t} / / \mathrm{b} /, / \mathrm{u} /$ & [na naykuan] & {$[\mathrm{n}],[\mathrm{n}],[\mathrm{k}]$} & [tabian] & [i] \\
\hline 9 & ilutere: & /topon/ & $/ \mathrm{y} /$ & [topo] & [y] & [topon] & {$[\mathrm{y}]$} \\
\hline 10 & -8 & /ontip/ & $/ \mathrm{n} /, / \mathrm{t} /, / \mathrm{p} /$ & [empil] & {$[\mathrm{m}],[\mathrm{p}],[1]$} & [pit..emtip] & {$[\mathrm{m}]$} \\
\hline & Total & & 23 & & 17 & & 6 \\
\hline
\end{tabular}

The segmental errors, such as $/ \mathrm{r} /, / \mathrm{h} /, / \mathrm{k} /, / \mathrm{s} /, / \mathrm{o} /, / \mathrm{d} /, / \mathrm{e} /, / \mathrm{t} /, / \mathrm{y} /$, and $/ \mathrm{m} /$, in pre-intervention were treated as target segments for rehabilitation. After the treatment, the participants were able to produce some correct words and the numbers of segmental errors were less even though the sounds $/ 1 /, / \mathrm{s} /, / \mathrm{k} /$, and $/ \mathrm{m} /$ in certain positions remained unchanged. The sound /s/ could not be articulated correctly and was substituted by glottal fricative /h/ at the end of word if and only if it was proceeded by rounded middle back vowel /o/. It means that the complexity of a segment was influenced by coarticulation and its position. The evidence presented that some high complex consonants could not be articulated correctly in initial position, e.g. /guru/ $\rightarrow$ [kulu], /guak/ $\rightarrow$ [kuak] but they were at ease when they appeared in final distribution, eg. /bədeg/ $\rightarrow$ [bədeg]. The complex consonants could not be articulated in a coarticulation with any vowels in initial distribution. Compared to a syndrome of self-correcting in initial distribution, KW was able to reduce repeating first and last syllable, but he failed to articulate the high complex consonants in initial.

2. Speech Outputs of NS

NS was given the same phonological task to recognize his speech outputs, and his phonological errors were rehabilitated with the same strategy. Though both participants suffered from the same type of aphasia, the segmental errors might be quite different. NS tended to mutate the segment in different positions though every single segment was correctly articulated. The segmental errors found were $/ \mathrm{b} /, / \mathrm{j} /, / \mathrm{k} /, / \mathrm{s} /, / \mathrm{b} /, / \mathrm{\jmath} /, / \mathrm{p} /, / \mathrm{u} /, / \mathrm{o} /, / \mathrm{y} /, / \mathrm{\jmath} /, / \mathrm{n} /, / \mathrm{r} /$. These segments were treated by applying the phonetic relaxation strategy to stimulate the articulator to blend and combine one segment with another. The complex sounds were trained to achieve better articulation. The evidence of segmental errors in preintervention and any change that occurred after post intervention can be presented below.

TABLE III.

THE Distribution of ERRORS PRODUCED By NS IN PHONETIC RELAXATION

\begin{tabular}{|c|c|c|c|c|c|c|c|}
\hline No & Word naming & Target word & $\begin{array}{c}\text { target } \\
\text { segment }\end{array}$ & $\begin{array}{c}\text { Segment } \\
\text { realization }\end{array}$ & $\begin{array}{l}\text { Segmental } \\
\text { errors }\end{array}$ & Post Intervention & $\begin{array}{l}\text { Segmental } \\
\text { error }\end{array}$ \\
\hline 1 & Baju 'shirt' & /baju/ & /b/, /j/ & [padu] & [p], [d] & [badu] & [d] \\
\hline 2 & Katos 'tuff' & /katos/ & $\begin{array}{c}/ \mathrm{k} /, / \mathrm{t} /, / \mathrm{o} /, \\
/ \mathrm{s} /\end{array}$ & [hatoh] & {$[\mathrm{h}],[\mathrm{s}]$} & [satos] & {$[\mathrm{s}]$} \\
\hline 3 & Kapak 'axe' & /kapak/ & /k/, /k/ & [tapak] & {$[\mathrm{k}]$} & [kapak] & - \\
\hline 4 & Bata 'brick' & /batə/ & $/ \mathrm{b} /, / \mathrm{t} /, / \mathrm{\partial} /$ & [tato] & {$[\mathrm{t}],[\mathrm{o}]$} & [ba..toh] & {$[\mathrm{o}],[\mathrm{h}]$} \\
\hline 5 & Papat 'four' & /papat/ & $/ \mathrm{p} /, / \mathrm{t} /$ & [tapat] & {$[\mathrm{t}]$} & [napat] & [n] \\
\hline 6 & & /sate/ & $/ \mathrm{s} /, / \mathrm{t} /$ & [cate] & [p] & [sace] & {$[\mathrm{t}]$} \\
\hline 7 & & /siap/ & /i/ & [ipas] & - & [sipa] & - \\
\hline 8 & & /tabuan/ & $/ \mathrm{t} /, / \mathrm{b} /, / \mathrm{u} /$ & [tabian] & {$[\mathrm{u}]$} & [tabuan] & - \\
\hline 9 & & /topon/ & $/ \mathrm{y} /$ & [topən] & {$[\mathrm{o}],[\mathrm{y}]$} & [topon] & [n] \\
\hline 10 & & /ontip/ & $/ \mathrm{n} /, / \mathrm{t} /, / \mathrm{p} /$ & [nitip] & /i/, /n/ & [nentip] & [n] \\
\hline & Total & & 23 & & 14 & & 8 \\
\hline
\end{tabular}


From 23 target consonants and vowels, NS made 14 phoneme substitution errors, however after the rehabilitation, only 8 phoneme errors were made. From the phonetic processing side of view, the target phonemes, /p/, /d/, /h/, /s/, /k/, $/ \mathrm{t} /, / \mathrm{o} /, / \mathrm{u} /, / \mathrm{y} /, / \mathrm{n} /$ were not able to be realized by NS due to the high complex articulation. The rehabilitation focused on blending the complex articulatory-based consonants, such as stop, fricative, and trill, with less complex vowels, such as low, back, rounded and lax $(/ \mathrm{a} /, / \mathrm{o} /, / \mathrm{I} /)$. After some training, patients were given the same words or pictures to say, and there were some decreasing errors, either in terms of number or of articulation quality. The segments that remained unchanged were $/ \mathrm{d} /, / \mathrm{s} /, / \mathrm{o} /, / \mathrm{h} /, / \mathrm{n} /, / \mathrm{t} /$. It was observed that e.g., the unvoiced velar stop consonant $/ \mathrm{k} /$ and unvoiced bilabial stop consonant $/ \mathrm{p} /$ in the word katos 'tuff' and papat 'four' could not be realized in onset due to the anterior lesion and it was substituted by $/ \mathrm{h} /$ and $/ \mathrm{t} /$. It can be noted here that $/ \mathrm{k} /$ and $/ \mathrm{p} /$ are the least sonorant sounds in the sonority scale, so they were altered by more sonorant segments, and they said [hatoh] and [tapak]. The decreasing segmental errors before and after the phonetic relaxation was applied can be presented in the following Fig. 1.

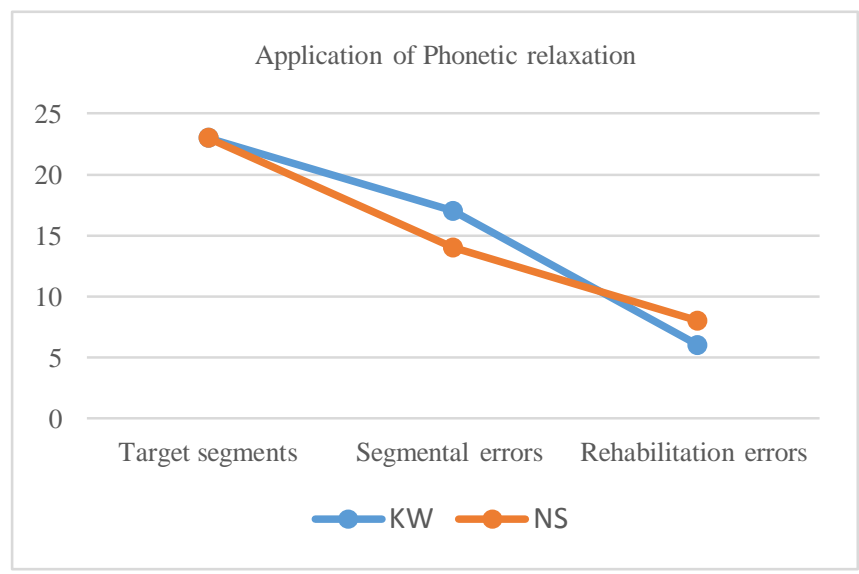

Figure1: Decreasing segmental errors of KW and NS in phonetic relaxation

\section{Suprasegmental Drills}

Based on the observation, individual sounds were able to be pronounced by the patients under study, however, they could not blend the sounds in sequencing syllables. The prosodic approach can be applied to help them sharpen the target words because the right hemisphere stays in great function. In fact, the application of suprasegmental drills is believed to be able to strengthen the role of the right hemisphere. The segments articulation may be so weak due to the failure of articulatory processing, but the prosody remains heard. The patients were trained to blend the sounds by drilling the segments with prosodic features, such as stress, intonation, and rhythm. To understand the sound outputs between pre-intervention and post-intervention of the two participants, the difference of errors of the two patients can be described below.

1. Speech outputs of KW

KW tended to make self-correcting efforts in naming or repeating words or pictures due to an incapability of judging the appropriate segments by repeating first syllables, doing metathesis, and repeating the last syllables. The phonemic errors were /u/, /s/, /b/, /t/, /a/, /a/, /d/, /l/, /n/, /n/, /y/, /k/, /s/, /a/, /g/ in all positions, and they were substituted by [o], [h], $[1],[\mathrm{k}],[\mathrm{s}],[\mathrm{p}],[\mathrm{t}],[\mathrm{w}],[\mathrm{n}],[\mathrm{b}],[\mathrm{n}]$. However, after the rehabilitation, some errors may have been reduced and some errors remained unchanged. There were some prolongation and devoicing cases which indicated a typical syndrome of anterior lesion. To find out the significance of the rehabilitation, the segmental errors in pre-intervention and treated segmental errors of $\mathrm{KW}$ in suprasegmental drills can be presented below. 
TABLE IV.

THE DISTRIBUTION OF ERRORS PRODUCED BY KW IN SUPRASEGMENTAL DRILLS

\begin{tabular}{|c|c|c|c|c|c|c|c|}
\hline No & Word naming & $\begin{array}{l}\text { Target } \\
\text { word } \\
\end{array}$ & $\begin{array}{l}\text { target } \\
\text { segment }\end{array}$ & $\begin{array}{l}\text { Segment } \\
\text { realization }\end{array}$ & $\begin{array}{l}\text { Segmental } \\
\text { errors }\end{array}$ & Post Intervention & $\begin{array}{l}\text { Segmental } \\
\text { error }\end{array}$ \\
\hline 1 & tebu 'sugar cane' & $/$ təbu/ & $/ \mathrm{u} /$ & [təboh] & {$[\mathrm{o}],[\mathrm{h}]$} & {$[\mathrm{t} ə . . . \mathrm{bu}]$} & - \\
\hline 2 & $s a a b$ 'cover' & /sa:b/ & $/ \mathrm{s} /, / \mathrm{b} /$ & [laəp] & {$[1]$} & [saeb] & - \\
\hline 3 & tatu 'wound' & /tatu/ & $/ \mathrm{t} /, / \mathrm{u} /$ & [akko] & {$[\mathrm{k}],[\mathrm{o}]$} & [tat..tou] & [o] \\
\hline 4 & bata 'brick' & /batə/ & /a/ & [da bat oh] & {$[\mathrm{o}],[\mathrm{h}]$} & [bat..to] & [o] \\
\hline 5 & atat 'parrot' & /atat/ & $/ \mathrm{a} /, / \mathrm{t} /$ & [satup-tep] & {$[\mathrm{s}],[\mathrm{p}]$} & [ta.tatap] & {$[\mathrm{p}]$} \\
\hline 6 & dauh 'west' & /daUh/ & $/ \mathrm{d} /, / \mathrm{h} /$ & [taoup] & {$[\mathrm{t}],[\mathrm{p}]$} & [dauh] & - \\
\hline 7 & aduh 'auch' & /adUh/ & $/ \mathrm{d} /$ & [pa.. atuh] & {$[\mathrm{t}]$} & [pa..tuh] & - \\
\hline 8 & natad 'lead' & / natad/ & $/ \mathrm{n} /, / \mathrm{t} /$ & [na....tad] & - & [natad] & - \\
\hline 9 & dedalu 'insect' & /dədalu/ & $/ \mathrm{d} /, / \mathrm{l} /$ & [dədaluh] & {$[\mathrm{h}]$} & [dədalu] & - \\
\hline 10 & nyambu 'guava' & /nambu/ & $/ \mathrm{n} /$ & [sawub] & {$[\mathrm{s}],[\mathrm{w}]$} & [nambu] & {$[\mathrm{n}]$} \\
\hline 11 & menyan 'wood' & /məjan/ & $/ \mathrm{n} /$ & [menan] & {$[\mathrm{n}]$} & [məji..an] & [i] \\
\hline 12 & saput 'blanket' & /sapUt/ & $/ \mathrm{t} /$ & [sapub] & [b] & [sa..put] & - \\
\hline 13 & уиуи 'crab' & /yuyu/ & $/ y /$ & [julUh] & {$[\mathrm{y}][1],[\mathrm{h}]$} & [yu..yu] & - \\
\hline 14 & buaya 'alligator' & /buayə/ & $/ \mathrm{y} /$ & [buanya] & [ny] & [bua.. iə] & - \\
\hline 15 & kasa 'clothe' & /kasə/ & $/ \mathrm{k} /$ & [sasə sə] & {$[\mathrm{s}]$} & [kas..sə] & - \\
\hline 16 & akah 'root' & lakah/ & $/ \mathrm{s} /, \mathrm{h} / /$ & [katas] & {$[\mathrm{s}]$} & [a..kah] & - \\
\hline 17 & pulu 'scale' & /pulu/ & $/ \mathrm{u} /, / \mathrm{l} /$ & [pou] & [1] & [pu.puluh] & {$[\mathrm{h}]$} \\
\hline 18 & guak 'crow' & /guak/ & $/ \mathrm{k} /$ & [kuak ku] & {$[\mathrm{k}]$} & [guah] & {$[\mathrm{h}]$} \\
\hline 19 & legu 'mosquito' & /logu/ & $/ \mathrm{u} /$ & [lego] & {$[\mathrm{o}]$} & [ləbu] & [b] \\
\hline \multirow[t]{2}{*}{20} & beteg 'swollen' & /botog/ & $/ \mathrm{\partial} /, / \mathrm{g} /$ & [botek] & {$[\mathrm{o}],[\mathrm{k}]$} & [bədəg] & - \\
\hline & Total & & 38 & & 28 & & 8 \\
\hline
\end{tabular}

The features of target sounds in word naming [+coronal, +anterior, +back, + high] are mainly substituted by segments with features of [anterior, +coronal, +rounded, + lateral]. High complex features were mainly substituted by lower complex features. In a case of voicing as part of articulatory planning deficit, the segments with [+voiced] can be substituted by segments with [-voiced] in certain environments, as presented in the following phonological rules in the target word of aduh 'ouch' which was realized as [atuh].

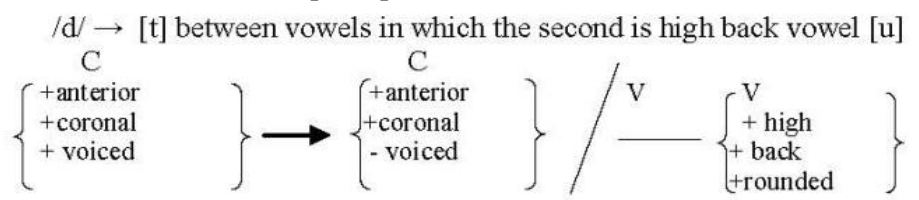

The substitution of segment /d/ into [t] occurred only when it was sequenced with $[\mathrm{u}]$ in middle distribution. The substitution of $/ \mathrm{k} /$ with [s] in the target word kase 'clothe' is mainly influenced by the following /s/ in second syllable. It was found that the patient KW tended to transpose the segment in the second syllable to onset of the first syllable.

2. Speech outputs of NS

The speech output of KW and NS presented specific differences in processing phonemic representation into phonetic realization though they suffered from the same aphasia. KW tended to transpose the syllable and self-correct the sound by repeating the first or final syllable, however NS transposed the segments randomly or without any certain patterns. Furthermore, NS tended to insert other segments when he failed to access the right sequence of phonemes because of an articulatory planning deficit. The target segments /p/, /t/, /k/, /d/, /g/, /s/, /c/, /r/, /l/, /n/, /i/, /e., /u/, /o/ and /a/ were realized in substitution, omission, or insertion processes as $[\mathrm{p}],[\mathrm{t}],[\mathrm{d}],[\mathrm{s}],[\mathrm{c}],[1],[\mathrm{i}],[\mathrm{\jmath}],[\mathrm{o}]$, and [a]. The segmental changes of the treated errors of NS in suprasegmental drills can be presented below. 
TABLE V.

THE DISTRIBUTION OF ERRORS PRODUCED BY NS IN SUPRASEGMENTAL DRILLS

\begin{tabular}{|c|c|c|c|c|c|c|c|}
\hline No & Word naming & Target word & target segment & $\begin{array}{l}\text { Segment } \\
\text { realization }\end{array}$ & $\begin{array}{l}\text { Segmental } \\
\text { errors }\end{array}$ & Post Intervention & $\begin{array}{l}\text { Segmental } \\
\text { error }\end{array}$ \\
\hline 1 & Pianak 'child' & /pianak/ & $/ \mathrm{p} /, / \mathrm{l} /, / \mathrm{k} /$ & [pilanak] & {$[1]$} & [pinanak] & {$[\mathrm{n}]$} \\
\hline 2 & Lelipi 'snake' & /ləlipi/ & $/ 1 /, / \mathrm{p} /$ & [tilətip] & {$[\mathrm{t}],[\vartheta]$} & [teləpi] & - \\
\hline 3 & Saip 'sieve' & /saIp/ & $/ \mathrm{s} /, / \mathrm{p} /$ & [atip] & {$[\mathrm{t}]$} & [sa...ip] & - \\
\hline 4 & Pecok 'damge' & /pecok/ & $/ \mathrm{e} /, / \mathrm{c} /, / \mathrm{o} /$ & [pitak] & {$[\mathrm{i}],[\mathrm{t}],[\mathrm{a}]$} & [petok] & [c] \\
\hline 5 & Tape 'food' & /tape/ & $/ \mathrm{t} /$ & [cape] & [c] & [tape] & - \\
\hline 6 & Gatep 'fruit' & /gatep/ & $/ \mathrm{e} /, / \mathrm{p} /$ & [gatit] & [a], [i], [p] & [hatep] & [h] \\
\hline 7 & Pepek 'spoil' & /pəpək/ & /a/ & [pəpak] & [a] & [pәpəh] & [h] \\
\hline 8 & Dupa 'stick' & /dupo/ & /d/ & [tupa] & {$[\mathrm{t}]$} & [du..pa] & - \\
\hline 9 & Getep 'cut' & /gətəp/ & /g/, /ə/ & [təp..titəp] & {$[\mathrm{t}],[\mathrm{i}]$} & [tətəp] & {$[\mathrm{t}]$} \\
\hline 10 & Pura 'tempel' & /pura/ & $/ \mathrm{r} /$ & [pululə] & [1] & [pu.. lə] & [1] \\
\hline 11 & Alu 'monitor' & /alu/ & $/ \mathrm{u} /$ & [alud] & [d] & [alu] & - \\
\hline 12 & Saup 'grab' & /saup/ & $/ \mathrm{s} /$ & [aup] & {$[\mathrm{s}]$} & [taup] & {$[\mathrm{t}]$} \\
\hline 13 & Polih 'obtain' & /polih/ & $/ \mathrm{o} /, / 1 /, / \mathrm{h} /$ & [pepit] & {$[\mathrm{e}],[\mathrm{p}],[\mathrm{t}]$} & [poleh] & [e] \\
\hline 14 & Nyumprit 'fall' & /numprit/ & $/ \mathrm{n} /, / \mathrm{r} /$ & [numplit] & {$[\mathrm{n}],[1]$} & [num...pelit] & - \\
\hline 15 & Prembon 'dance' & /prembon/ & $/ \mathrm{p} /, / \mathrm{e} /$ & [tobron] & {$[\mathrm{t}],[\mathrm{o}]$} & [plem...nbonm] & {$[\mathrm{n}]$} \\
\hline 16 & Prumpung 'old' & / prumpuy/ & $/ \mathrm{p} /, / \mathrm{r} /$ & [tlumpun] & {$[\mathrm{t}],[1]$} & [plun..mpun] & [n] \\
\hline 17 & Semprong 'pipe' & /semproy/ & $/ \mathrm{s} /, / \mathrm{r} /$ & [təmplon] & {$[\mathrm{t}],[1]$} & [senm..pron] & {$[\mathrm{n}]$} \\
\hline 18 & Pragat 'finish' & /pragat/ & $/ \mathrm{r} /, / \mathrm{g} /$ & [plapat] & {$[1],[\mathrm{p}]$} & [pla..gat] & [1] \\
\hline 19 & Pripit 'stingy' & /pripit/ & $/ \mathrm{p} /, / \mathrm{r} /, / \mathrm{i} /$ & [təplit] & [p], [1], [ə] & [pli....plit] & [1] \\
\hline \multirow[t]{2}{*}{20} & Uled 'caterpilar' & /uləd/ & $/ \mathrm{u} /, / \mathrm{d} /$ & [olep] & {$[\mathrm{o}],[\mathrm{p}]$} & [uh..ləb] & [h] \\
\hline & Total & & 38 & & 36 & & 14 \\
\hline
\end{tabular}

From the 38 target segments, the phonological errors in pre-intervention were 36 segments, including substitution, omission, insertion, and distortion and after the errors were treated through suprasegmental drills, NS could reduce the transposing of segments, repeating syllables and substitution, and only 14 remained unchanged. From the final result of the treatment, it was found that the number of errors remained in a small amount and the segments were selected by NS because the target was so difficult to be accessed, such as stop, fricative and velar sounds which were altered by [n], [c], $[\mathrm{h}],[\mathrm{t}],[\mathrm{n}],[\mathrm{l}]$, and [e]. The reduction of sound errors in suprasegmental drills mirrors the effective influence of blending the sound in the prosodic approach. The segmental errors, after this strategy was applied, can be presented in the following figure Fig. 2.

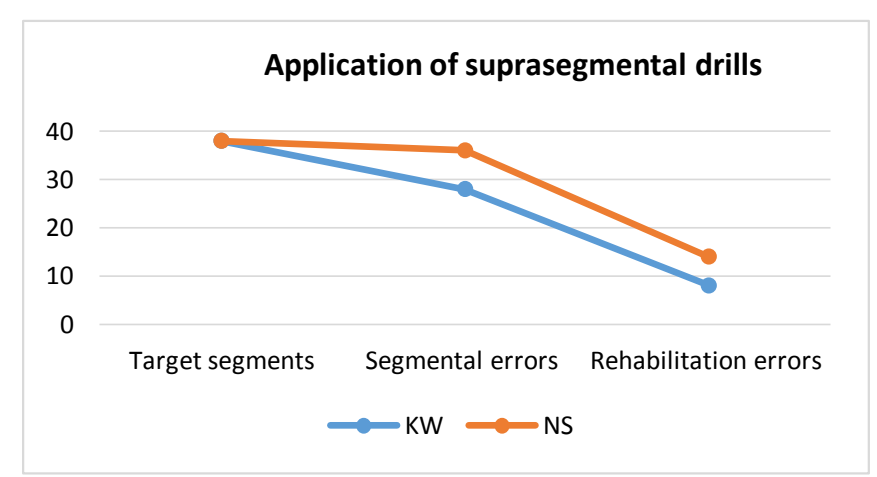

Figure 2: Decreasing segmental errors of KW and NS in suprasegmental drill

\section{Segmental Simulation}

The last strategy of the error-based rehabilitation model is called segmental simulation. This strategy can stimulate the patients' phonological awareness to combine two or three segments. When the segment is articulated, the articulators anticipate the coming segments' usual vowels that can influence the change or modify the preceding segment, as, in generative phonology, this process is known as assimilation. This strategy is applied to stimulate the phoneme and phonetic awareness to change the initial condition of articulatory deficits. The use of pictures and words completion involved in this strategy can stimulate the accuracy of articulatory judgment. Both patients were given the same training but the treated words were different, depending on the target words they mostly made. The condition of phonological errors in pre-intervention and post-intervention of two participants can be presented below.

1. Speech Outputs of KW

The efficacy of phonological rehabilitation for aphasic patients is considered significant and successful if the therapists use various kinds of sensory stimuli, e.g., audio stimuli, such as songs, words-rhyme sequencing models and visual stimuli, such as pictures, flash cards or any other signs applied in routine training. The increasing difficulty in speech stimulation may result in a better achievement. The phonological errors rehabilitation can be analyzed by different sides of theoretical views, e.g., brain function. Luria (1973) argues that the basic functional system in a brain zone consists of primary, secondary and lateral areas. Therefore, it is underlined that the rehabilitation concept is 
concerned with restoration of a specific function. To find out the significance of the rehabilitation, the segmental errors in pre-intervention and post-intervention can be presented below.

TABLE VI.

The Distribution OF ERRORS PRODUCED By KW IN SEGMENTAL Simulation

\begin{tabular}{|c|c|c|c|c|c|}
\hline No & Word naming & Target word & $\begin{array}{l}\text { Segment } \\
\text { realization }\end{array}$ & Post Intervention & $\begin{array}{l}\text { Segmental } \\
\text { error }\end{array}$ \\
\hline \multirow[t]{3}{*}{1} & Pianak'children' & /pianak/ & [pilanak] $\rightarrow[1]$ & [pi..pianak] & - \\
\hline & Somah 'husband' & /somah/ & {$[\mathrm{omah}] \rightarrow[\mathrm{s}]$} & [..somah] & - \\
\hline & Pianak somah 'family' & /pianak somah/ & {$[$ pinanak tomah] $\rightarrow[\mathrm{n}],[\mathrm{t}]$} & [pinanak somah] & {$[\mathrm{n}]$} \\
\hline \multirow[t]{3}{*}{2} & Tabia 'papper' & /tabia/ & {$[$ tapi yə] $\rightarrow[\mathrm{p}],[\mathrm{y}]$} & [tadiə] & [d] \\
\hline & Barak 'red' & /barak/ & {$[$ balak $] \rightarrow[1]$} & [balrak] & [1] \\
\hline & tabia-barak 'red papper' & /tabiə barak/ & [tabiyə banlak] $\rightarrow[\mathrm{n}]$ & [tabiə banlak] & {$[\mathrm{n}]$} \\
\hline \multirow[t]{3}{*}{3} & Nasi 'rice' & /nasi/ & {$[$ masih $] \rightarrow[\mathrm{m}],[\mathrm{h}]$} & [nasi] & - \\
\hline & Jagung 'corn' & /jagung/ & {$[$ dabun $] \rightarrow[\mathrm{d}],[\mathrm{b}]$} & [dabuy] & {$[\mathrm{d}],[\mathrm{b}]$} \\
\hline & Nasi jagung 'rice corn' & /nasi jagung/ & [nasi..jaduy] [j], [d] & [nasi..jadun] & [d] \\
\hline \multirow[t]{3}{*}{4} & Kuah 'soup' & /kuah & {$[$ guah $] \rightarrow[\mathrm{k}]$} & [kuah] & - \\
\hline & Pindang 'fish' & /pinday/ & {$[$ pimnda $] \rightarrow[\mathrm{m}]$} & [mpi..nday] & {$[\mathrm{m}]$} \\
\hline & Kuah pindang 'fish soup' & /kuah pinday/ & {$[$ kuah mpin.. dan] $\rightarrow[\mathrm{m}]$} & [kuah min.. day] & {$[\mathrm{m}]$} \\
\hline \multirow[t]{3}{*}{5} & Biu 'banana' & /biu/ & {$[$ biyuk $] \rightarrow[\mathrm{k}]$} & [biyuk] & {$[\mathrm{k}]$} \\
\hline & Кауи 'wood' & /kayu/ & [kayu $]$ & [kayu $]$ & - \\
\hline & Biu kayи 'banana' & /biu kayu/ & [biyuh kayu] $\rightarrow[\mathrm{h}]$ & [biyuh kayu] & {$[\mathrm{h}]$} \\
\hline \multirow[t]{3}{*}{6} & Siap 'chicken' & /siap/ & {$[\mathrm{seap}] \rightarrow[\mathrm{e}]$} & [siap] & - \\
\hline & Selem 'black' & /sələm/ & {$[$ pənlem $] \rightarrow[\mathrm{s}],[\mathrm{n}]$} & [pənlem] & [p] \\
\hline & Siap selem 'black chicken' & /siap sələm/ & {$[\mathrm{sa} .$. siap pənləm] $\rightarrow[\mathrm{p}],[\mathrm{n}]$} & [sa..siap sənləm] & {$[\mathrm{n}]$} \\
\hline 7 & Pura dalem 'temple' & /purə daləm/ & {$[$ pulə da..nləm] $\rightarrow[1],[\mathrm{n}]$} & [pulə da..nləm] & {$[\mathrm{n}]$} \\
\hline 8 & Krapat-kripit'slow action' & $\begin{array}{l}\text { /krapat kripit/ } \\
32\end{array}$ & $\begin{array}{l}\text { [tolapat plip plit tit } \rightarrow[\mathrm{t}],[1], \\
28\end{array}$ & [tolapat plip plit tit & $\begin{array}{l}{[\mathrm{t}],[\mathrm{o}],[1]} \\
17\end{array}$ \\
\hline
\end{tabular}

The segmental errors made by KW in pre-intervention were $[1],[s],[n],[t],[p],[y],[1],[n],[m],[h], d],[b],[j],[d]$, $[\mathrm{k}],[\mathrm{h}],[\mathrm{e}]$. These errors were dominated by the features [+obstruent], [+nasal], [+liquid], [+glide] and [+vowel]. These phonemes were treated for rehabilitation that resulted in the reduction of errors. Some segments in target words were able to be well articulated, however some features of segments remained unchanged due to phonetically based complexity features, such as [+nasal], [+obstruent], [+lateral], and [vowel]. The difficulties raised due to the inaccuracy of articulatory processing are a typical syndrome of Broca's aphasia.

1. Speech outputs of NS

Increasing the complexity of the words structure for sounds errors rehabilitation can help the patients practice manipulating the articulators to produce correct phonetic realization. The patients were given more complex words that consisted of consonant clusters. Both KW and NS could say single segment alone and segments in single sequencing words but both of them could not produce two or three complex words at ease. It can be noticed that the more complex the articulation works, the more substitution errors occur as well as the more complex the words are sequenced, the harder the patients blend the sounds. NS made phonological errors in two complex compound words though he almost uttered the single words correctly. The segments treated for rehabilitation were $[\mathrm{t}],[\mathrm{d}],[\mathrm{k}],[\mathrm{h}],[1],[\mathrm{j}],[\mathrm{y}],[1],[\mathrm{p}],[\mathrm{e}]$, $[\mathrm{u}]$. The segmental training focused on articulatory judgment on words by words in single sequence, and they were stimulated with more complex two words. The segmental errors in pre-intervention and the change in post-intervention can be presented below. 
TABLE VII.

THE DisTRIBUtion OF ERRORS PRODUCED BY NS IN SEGMENTAL SiMULATION

\begin{tabular}{|c|c|c|c|c|c|}
\hline No & Word naming & Target word & $\begin{array}{l}\text { Segment } \\
\text { realization }\end{array}$ & Post Intervention & $\begin{array}{l}\text { Segmental } \\
\text { error }\end{array}$ \\
\hline \multirow[t]{3}{*}{1} & biu 'banana' & /biu/ & {$[$ biyuk $] \rightarrow[\mathrm{k}]$} & [bi..yu] & - \\
\hline & matah 'unripe'" & /matah/ & [matah] & [matah] & - \\
\hline & biu matah 'unripe benana' & /biu matah/ & [biyuh mua..tah] $\rightarrow[\mathrm{u}]$ & [biu matah] & - \\
\hline \multirow[t]{3}{*}{2} & payuk 'pan' & /payuk/ & {$[$ pauk $] \rightarrow[y]$} & [pah..yuk] & {$[\mathrm{h}]$} \\
\hline & prumpung 'old' & /prumpuy/ & [pəlumpun] $\rightarrow[ə],[1]$ & [tlumpun] & {$[\mathrm{t}],[1]$} \\
\hline & payuk prumpung 'old pan' & /payuk prumpuy/ & [payuh pun..pun] $\rightarrow[\mathrm{h}],[1]$ & [payuk pəlunpun] & {$[1]$} \\
\hline \multirow[t]{3}{*}{3} & kopi 'coffee' & /kopi/ & {$[$ kopik $] \rightarrow[\mathrm{k}]$} & [koh..pi] & [h] \\
\hline & manis 'manis' & /manis/ & {$[$ manes $] \rightarrow[\mathrm{e}]$} & [manis] & - \\
\hline & kopi manis 'sweet coffee' & /kopi manis/ & {$[$ kopih ma..nis $] \rightarrow[\mathrm{e}]$} & [kopi man..lis] & {$[\mathrm{n}]$} \\
\hline \multirow[t]{3}{*}{4} & kuah 'soup' & /kuah/ & {$[\mathrm{oah}] \rightarrow[\mathrm{k}],[\mathrm{u}]$} & [kuah] & - \\
\hline & pindang 'fish' & /pindang/ & {$[$ pindan $] \rightarrow[\mathrm{y}]$} & [pim,ndan] & {$[\mathrm{m}]$} \\
\hline & Kuah pindang 'fish soup' & /kuah pindang/ & {$[$ kuak ..pin.day] $\rightarrow[\mathrm{k}],[\mathrm{y}]$} & [kuah mpin day] & [m] \\
\hline \multirow[t]{3}{*}{5} & biu 'banana' & /biu/ & /biyuk/ $\rightarrow[\mathrm{k}]$ & [biyu] & - \\
\hline & kayu 'wood' & /kayu/ & $/ \mathrm{kaju} / \rightarrow[\mathrm{j}]$ & [kahyuh] & {$[\mathrm{h}]$} \\
\hline & biu kayu 'a type of banana' & /biu kayu/ & $/$ biuh ka..kadu/ $\rightarrow[\mathrm{h}],[\mathrm{d}]$ & [biu kayo] & [o] \\
\hline \multirow[t]{3}{*}{6} & siap 'chicken' & /siap/ & $/$ seyap/ $\rightarrow[\mathrm{e}],[\mathrm{y}]$ & [si..ap] & - \\
\hline & selem 'black' & /selem/ & $/$ tələm $/ \rightarrow[\mathrm{t}]$ & [pən..ləm] & {$[\mathrm{p}]$} \\
\hline & siap selem 'black chicken' & /siap selem/ & /siap kələm/ $\rightarrow[\mathrm{k}]$ & [siap nələm] & {$[\mathrm{n}]$} \\
\hline 7 & pura dalem 'temple' & /pura dalem/ & /pululə dahlem/ $\rightarrow[1],[\mathrm{h}]$ & [pulə daləm] & [1] \\
\hline \multirow[t]{2}{*}{8} & krapat-kripit 'slow action' & /krapat-kripit/ & kulapat tlipit..pit $/ \rightarrow[1],[\mathrm{k}]$ & Klapat klinpit] & [1] \\
\hline & & 32 & 27 & & 14 \\
\hline
\end{tabular}

The 27 segmental errors produced by NS in articulating those complex words consisted of the stop, fricative, and lateral sounds. Those segments were treated for rehabilitation and resulted in the reduction of errors. The remaining errors after rehabilitation were [p], [t], [m], [n], [l], [h] and [o]. The substitution errors mainly occurred when the right sequence of phonemes could not be accessed because of information decays in a phonological output buffer. The patients, in such a way, justified the difficulty by selecting low complex articulation. In the following Fig. 3, the evidence of natural errors was investigated and revealed the decreasing errors after the segmental simulation was applied.

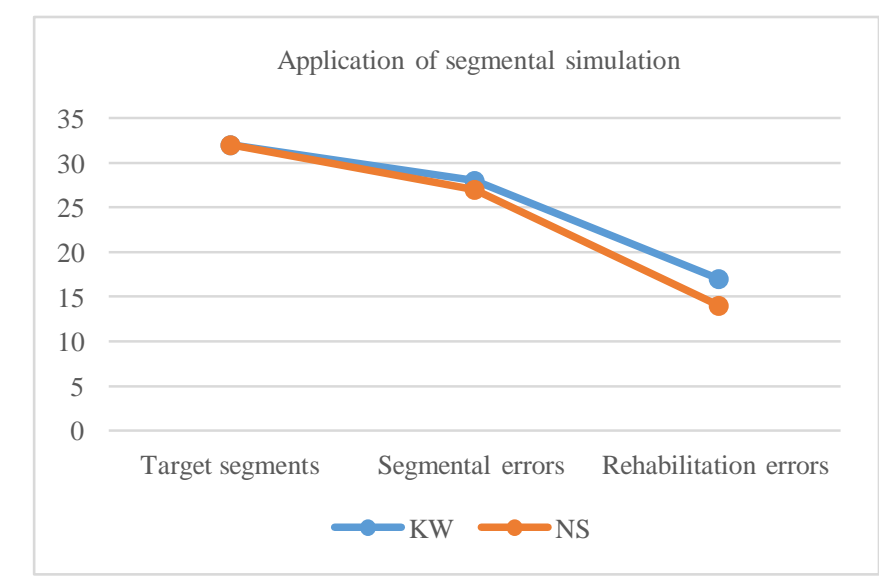

Figure 3: Decreasing segmental errors of KW and NS in segmental simulation

The phonological errors in post-intervention produced by KW and NS were much less than in pre-intervention. Referring to the figure above, there was a reduction of errors quantity in vowels and consonants produced by KW and NS. The character of articulation approached the normal variation. The description of errors in two parameters of Balinese segments produced by patients with Broca's aphasia in the initial condition and the changes after rehabilitation can be presented below. 
TABLE VIII.

THE SEgMENTAL CHANGES THROUGH PHONOLOGICAL ERRORS-BASEd ReHABILITATION MODEL

\begin{tabular}{|c|c|c|c|}
\hline No & Vowels/ consonant & Phonemes substitution errors & Error based Rehabilitation \\
\hline 1 & i & $/ \mathrm{i} / \rightarrow[\mathrm{e}],[\mathrm{a}]$ & $/ \mathrm{i} / \rightarrow[\mathrm{I}],[\mathrm{e}]$ \\
\hline 2 & $\mathrm{e}$ & $/ \mathrm{e} / \rightarrow[\ominus],[\mathrm{I}]$, & $/ \mathrm{e} / \rightarrow[\mathrm{I}]$ \\
\hline 3 & $\mathrm{u}$ & $/ \mathrm{u} / \rightarrow[ə],[æ]$ & $/ \mathrm{u} / \rightarrow[\mathrm{U}]$ \\
\hline 4 & o & $/ \mathrm{o} / \rightarrow[\mathrm{e}],[\mathrm{U}]$ & $/ \mathrm{o} / \rightarrow[\mathrm{o}]$ \\
\hline 5 & a & $/ \mathrm{a} / \rightarrow[\mathrm{o}],[\mathrm{o}]$ & $/ \mathrm{a} / \rightarrow[\mathrm{a}]$ \\
\hline 6 & $\mathrm{p}$ & $/ \mathrm{p} / \rightarrow[\mathrm{p}],[1]$ & $/ \mathrm{p} / \rightarrow[\mathrm{h}]$ \\
\hline 7 & $\mathrm{t}$ & $/ \mathrm{t} / \rightarrow[\mathrm{p}],[\mathrm{h}],[\mathrm{k}],[\mathrm{s}],[\mathrm{c}]$ & $/ \mathrm{t} / \rightarrow[\mathrm{d}]$ \\
\hline 8 & $\mathrm{k}$ & $/ \mathrm{k} / \rightarrow[\mathrm{t}],[\mathrm{g}],[\mathrm{s}],[\mathrm{h}]$ & $/ \mathrm{k} / \rightarrow[\mathrm{p}]$ \\
\hline 9 & $\mathrm{~m}$ & $/ \mathrm{m} / \rightarrow[\mathrm{b}]$ & $/ \mathrm{m} / \rightarrow[\mathrm{m}]$ \\
\hline 10 & $\mathrm{n}$ & $/ \mathrm{n} / \rightarrow[\mathrm{m}]$ & $/ \mathrm{n} / \rightarrow[\mathrm{n}]$ \\
\hline 11 & $\mathrm{~s}$ & $/ \mathrm{s} / \rightarrow[\mathrm{t}],[\mathrm{k}] .[1],[\mathrm{w}]$, & $/ \mathrm{s} / \rightarrow[\mathrm{n},[\mathrm{t}]$ \\
\hline 12 & $\mathrm{c}$ & $/ \mathrm{c} / \rightarrow[\mathrm{p}],[\mathrm{s}]$ & $/ \mathrm{c} / \rightarrow[\mathrm{t}],[\mathrm{s}]$. \\
\hline 13 & $\mathrm{j}$ & $/ \mathrm{j} / \rightarrow[\mathrm{b}],[\mathrm{l}],[\mathrm{d}]$, & $/ \mathrm{j} / \rightarrow[]$ \\
\hline 14 & $\mathrm{~h}$ & $/ \mathrm{h} / \rightarrow[\mathrm{p}],[\mathrm{s}]$ & $/ \mathrm{h} / \rightarrow[?]$ \\
\hline 15 & $\mathrm{~b}$ & $/ \mathrm{b} / \rightarrow[\mathrm{p}],[\mathrm{n}]$ & $/ \mathrm{b} / \rightarrow[\mathrm{p}]$ \\
\hline 16 & $\mathrm{~d}$ & $/ \mathrm{d} / \rightarrow[\mathrm{t}],[\mathrm{b}]$ & $/ \mathrm{d} / \rightarrow[\mathrm{t}]$ \\
\hline 17 & $\mathrm{~g}$ & $/ \mathrm{g} / \rightarrow[\mathrm{k}],[\mathrm{t}],[\mathrm{d}]$. & $/ \mathrm{g} / \rightarrow[\mathrm{h}],[\mathrm{b}]$ \\
\hline 18 & $\mathrm{n}$ & $/ \mathrm{n} / \rightarrow[\mathrm{n}],[\mathrm{s}],[\mathrm{y}]$ & $/ \mathrm{n} / \rightarrow[\mathrm{n}]$ \\
\hline 19 & y & $/ \mathrm{y} / \rightarrow[\mathrm{m}]$ & $/ \mathrm{y} / \rightarrow[\mathrm{n}]$ \\
\hline 20 & $\mathrm{r}$ & $/ \mathbf{r} / \rightarrow[1]$ & $/ \mathrm{r} / \rightarrow[1]$ \\
\hline 21 & $\mathrm{w}$ & $/ \mathrm{w} / \rightarrow[\mathrm{y}],[\mathrm{r}]$ dan $[\mathrm{n}]$. & $/ \mathrm{w} / \rightarrow[\mathrm{a}]$ \\
\hline
\end{tabular}

The vowels substitution errors were considered rare, however, the alteration clearly appeared in the form of distortion as typical speech output syndrome of the anterior lesion, e.g. the word ipah 'brother in law' was realized as [aleh]. Distortion in phonetic errors refers to inaccurate and unrecognizable phonemes production (Darley, 1975). After the vowel errors rehabilitation, the alteration of vowels occurred in the form of simplification, e.g tense vowel [i] was altered by $[\mathrm{I}]$ and prolongation. It is not just because the vowels are easier to be produced but the training of articulatory stimulation could bring habitual formation.

Phonological errors produced by the patients were influenced by some factors, such as level of articulatory planning deficit, psychological readiness, and medical condition. Specifically, the phonemes substitution errors were mainly caused by the inability to start the first phonemes of the words, to blend one sound with another, and to present the high complexity of phonemes articulation. The phonological process occurred in terms of neighboring sounds which was, of course, related to the articulatory base. NS could not start the first phoneme of the word sumping 'cake', so he substituted $/ \mathrm{s} /$ with $[\mathrm{n}]$ because the articulators anticipated the coming nasal $/ \mathrm{m} /$ resulting in an assimilation process (Schane (1992), and that was why /sumpin/ was realized as [numpin]. Bastiaanse, Gilbers \& Linde (1994) consider this as a phoneme substitution sonority, a term that refers to the substitution of one segment in sonority group with another segment which is only one level more sonorant in sonority scale leading to a syllable peak.

\section{CONCLUSION}

The answers to the research questions above can be summarized that KW and NS performed different segmental errors and types of the phonological process even though they suffered from some identic syndromes of non-fluent aphasia. The phonemic representation, which was obscured by phonetic realization, resulted in articulation errors. This study revealed evidence that $\mathrm{KW}$, in pre-intervention, tended to present phonemes substitution errors and a small percentage of omission, and insertion errors which mostly occurred in the onset of syllables. He transposed the onset of the second syllable to the onset of the first syllable. The patterns of articulatory deficits of KW showed the features of $[+$ stop $] \rightarrow[+$ fricative $],[$-anterior $] \rightarrow[+$ coronal $],[$-anterior, -coronal $] \rightarrow[+$ coronal $],[+$ voiced $] \rightarrow[$-voiced $],[+$ high $] \rightarrow[-$ high], and [-lateral] $\rightarrow$ [+lateral]. He could not articulate stop sounds completely in initial distribution well due to the complexity of closure articulation as well as the trill sound /r/ was realized as lateral [1] in all positions because the patients could not rise, vibrate and glide the tongue across the hard palate. Meanwhile, NS, in some cases, tended to transpose the phonemes randomly, inserted other segments especially [+nasal] and [lateral] between two vowels (hiatuses) and altered the high complex segments with less complex articulatory based segments. The omission and insertion mostly occurred in the onset of the syllable. The more complex the sound was articulated, the more possibility that the sound was substituted, especially by a more sonorant segment. The phonological error-based rehabilitation was effective to reduce the errors of both patients in which the phonetic relaxation obtained minor errors. This indicated that phonetic based training can stimulate the articulatory deficit of anterior syndrome. However, all strategy solved the substitution errors which are influenced by neighboring segments in the featured groups of sonority scale.

\section{ACKNOWLEDGMENTS}

The authors wish to thank the patients and their family for their assistance with this study, and acknowledge that this research is supported in part by a grant from Indonesian lecturer's scholarship no 20161141111537. The committee of Badung Regional Public Hospital has approved and permitted the authors to receive the data based on the privacy rights 
of patients. The authors report no conflict of interest associated with this work and the authors are responsible for the content of this paper.

\section{REFERENCES}

[1] Bambini, V. (2012). Neurolinguistics. In J.O Otsman., J. Verschueren. Hands book of Pragmatics (pp.1- 29). John Benjamin Publishing Company.

[2] Bastiaanse, R., Dicky D. Gilbers \& Klarien v. d Linde. (1994). Sonority substitutions in Broca's and conduction aphasia. Journal of Neurolinguistics, 8 (4), 247-255. DOI: 10.1016/0911-6044(94)90011-6.

[3] Benson, D.F. (1979). Aphasia, alexia, and agraphia. New York: Churchill Livingstone.

[4] Blumstein, S.E (1973). A Phonological investigation of aphasic Speech. Mouton: The Hague.

[5] Cera, M.L \&/ Karin, Z. Ortiz (2010). Phonological analysis of substitution errors of patients with apraxia of speech. Dement Neuropsychol, 4 (1):58-62. DOI: 10.1590/S1980-57642010DN40100010.

[6] Darley, F.L, A. Aronson, \& J.R Brown (1975). Motor speech disorders. Philadelphia, London, Toronto: Saunders.

[7] Gandour, J.T. (1998). Phonetics and Phonology. In B. Stemmer., H.A. Whitaker. Handbook of Neurolinguistics, Indiana: Academic Press, 207 - 218.

[8] Howard, D. (2006). Distinguish semantic and lexical word retrieval deficits in people with aphasia. Aphasiology, 20 (9-11), 130. DOI: 10.1080/02687030600782679.

[9] Hesketh, A., C. Adams, C. Nightingale, \& R. Hall. (2000). Phonological awareness therapy and articulatory training aprroaches for children with phonological disorder: A comparative outcome study. International journal of language and communication disorders, 35 (3) 337-354.

[10] Kemmerer, D. (2014). Neurolinguistics: Mind, Brain and Language. In K. Allan (Ed). The Routledge Handbook of Linguistics New York: Routledge, 1-14.

[11] Kendal, D.L., T. J. Conway, Rosenbek, \& L.J. Rothi. (2003). Phonological Rehabilitation of acquired Phonological Alexia. Aphasiology, 17 (11), 1073-1095. DOI: 10.1080/02687030344000355.

[12] Lesser, R. (1995). Linguistic investigations of aphasia. London: Whurr Publishers.

[13] Lieberman, P \& S.E. Blumstein. (1988). Speech physiology, speech perception, and acoustic phonetics. New York: Cambridge University Press.

[14] Luria, A.R. (1973). The working brain: An introduction to neuropsychology. New York, NY: Basic Books.

[15] Musso, C. Weiller, S. Kiebel, S.P Muller, P. Bulau, \& M. Rijntjes (1999).). Training-Induced brain plasticity in aphasia. Brain, $122,1781-1790$.

[16] Novick, J.M., J.C. Trueswell, S. Thompsom \& L. Sharon. (2010). Broca's area and language processing: Evidence for the cognitive control connection". Language and Linguistics Compass 4: 906-924. DOI: 10.1111/j.1749-818X.2010.00244x.

[17] Pascoe, M., J. Stackhouse, \& B. Wells (2004). Phonological therapy within a psycholinguistic framework: Promoting change in a child with persisting speech difficulties. International Journal. Language Communication Disorder, 3900, 1-32. DOI: $10.1080 / 13682820412331290979$.

[18] Robson J, J. Marshall, T. Pring, \& S. Chiat. (1998). Phonological naming therapy in jargon aphasia: Positive but paradoxical effects. Journal of the International Neuropsychological Society, 4, 675- 686.

[19] Romani, C \& A. Calabrese. (1998). Syllabic constraints in the phonological errors of an aphasic patient. Brain and Language. 64, 83-121. DOI: 10.1006/brln.1998.1958.

[20] Schane, S. B. (1992). Generative phonology. San Diego: Prentice hall.Inc.

[21] Sengkey, L.S \& P. Pandeiroth (2014). Mirror therapy in stroke rehabilitation. Journal Biomedic, 6 (2) 84-90.

[22] Ziegler, W \& I. Aichert. (2015). How much is a word? Predicting ease of articulation planning from apraxic speech error patterns. Cortex, 69, 24-39.

[23] Luria, A. R. (1973). The working brain: An introduction to neuropsychology. New York, NY: Basic Books

I Ketut Wardana is a doctoral student in the faculty of Culture Study, Udayana University, Bali, Indonesia. He was born on 30 th September 1971 in Bali. He earned his Bachelor of Education degree in 2008 and later a Masters of Linguistic degree with a special focus on Gender Discourse in $2011 \mathrm{He}$ is currently working on his Ph.D. project on the phonological disorder of patients with Broca's aphasia. His interests are phonology and neurolinguistics.

I Nyoman Suparwa is a Professor in Linguistics at Udayana University, Bali, Indonesia. His Bachelor degree was earned at Udayana University in 1984 and graduated his master degree in Linguistics from Hasanuddin University in 1993. He earned his Doctorate degree in Linguistics from Udayana University in 2008. His research mainly focuses on phonetics and phonology. He engages as a vice dean, a reviewer, and a supervisor of many theses and dissertations. He spends his time on numerous national and international conferences, books and articles.

Made Budiarsa is a Professor in Linguistics at Udayana University, Bali, Indonesia. His Master degree in Linguistics was earned from Sydney University in 1988 and his Doctorate degree in Linguistics was earned from Gajah Mada University, Jogyakarta, Indonesia in 2006. His research mainly focuses on sociolinguistics and other wide range of linguistics. He engages as reviewer supervisor of many theses and dissertations. He spends his time on numerous national and international conferences, books and articles. 
Agung Putu Putra is a Doctor in inguistics at Udayana University, Bali, Indonesia. His Bachelor degree was earned at Udayana University in 1985 and his master degree in Linguistics was earned at Hasanuddin University in 1993. He earned his Doctorate degree in Linguistics from Udayana University in 2007. His research mainly focuses on dialectology and phonology. He engages as a lecturer, a reviewer, and a supervisor of many theses and dissertations. He spends his time on numerous national and international conferences, books and articles. 